\title{
Carbonylchromium Derivatives of Bismuth: New Syntheses and Relevance to $\mathbf{C}-\mathbf{O}$ Activation
}

\author{
Minghuey Shieh, $*[a]$ Jiann-Jang Cherng, ${ }^{[a]}$ Yun-Wen Lai, ${ }^{[a]}$ Chuen-Her Ueng, ${ }^{[a]}$ \\ Shie-Ming Peng, ${ }^{[b]}$ and Yi-Hung Liu $^{[b]}$
}

\begin{abstract}
We have discovered a series of novel pentacarbonylchromium derivatives of bismuth from the reactions of $\mathrm{NaBiO}_{3}$ with $\left[\mathrm{Cr}(\mathrm{CO})_{6}\right]$ in $\mathrm{KOH} / \mathrm{MeOH}$ solutions. When the reaction was carried out at room temperature, the highly charged $\left[\mathrm{Bi}\left\{\mathrm{Cr}(\mathrm{CO})_{5}\right\}_{4}\right]^{3-}$ (1) was obtained, whose structure was shown by $\mathrm{X}$-ray analysis to possess a central bismuth atom tetrahedrally coordinated to
\end{abstract}

four $\left[\mathrm{Cr}(\mathrm{CO})_{5}\right]$ groups. As the reaction was heated at $80^{\circ} \mathrm{C}$, the methyl-substituted complex $\left[\mathrm{MeBi}\left\{\mathrm{Cr}(\mathrm{CO})_{5}\right\}_{3}\right]^{2-}(\mathbf{2})$ was obtained, presumably via the $\mathrm{C}-\mathrm{O}$ activation of $\mathrm{MeOH}$. Further reactions of 1 with $\mathrm{CH}_{2} \mathrm{Cl}_{2}$ or $\mathrm{CH} \equiv \mathrm{CCH}_{2} \mathrm{Br}$ form

Keywords: bismuth • carbonyl ligands $\cdot \mathrm{C}-\mathrm{O}$ activation $\cdot$ chromium the halo-substituted complexes [XBi$\left.\left\{\mathrm{Cr}(\mathrm{CO})_{5}\right\}_{3}\right]^{2-}(\mathrm{X}=\mathrm{Cl}, \mathbf{3} ; \mathrm{Br}, 4)$, respectively. On the other hand, the reactions of 1 with $\mathrm{RI}(\mathrm{R}=\mathrm{Me}, \mathrm{Et})$ led to the formation of the alkyl-substituted complexes $\left[\mathrm{RBi}\left\{\mathrm{Cr}(\mathrm{CO})_{5}\right\}_{3}\right]^{2-}(\mathrm{R}=\mathrm{Me}, \mathbf{2} ; \mathrm{Et})$. The formation of complexes $\mathbf{1 - 4}$ is discussed, presumably via the intermediate bismuthinidene $\left[\mathrm{Bi}\left\{\mathrm{Cr}(\mathrm{CO})_{5}\right\}_{3}\right]^{-}$or the trianion $\left[\mathrm{Bi}\left\{\mathrm{Cr}(\mathrm{CO})_{5}\right\}_{3}\right]^{3-}$.

\section{Introduction}

Although Hieber et al. published the general syntheses of main-group-iron carbonyl complexes several decades ago, this methodology only worked nicely for the Fe system..$^{[1,2]}$ Recently, the Mn system was studied by using $\mathrm{K}_{2} \mathrm{TeO}_{3}$ and $\left[\mathrm{Mn}_{2}(\mathrm{CO})_{10}\right]$ in superheated $\mathrm{MeOH}$; this gave rise to a series of tellurium-bridging manganese carbonylates. ${ }^{[3]}$ For the early transition metal $\mathrm{Cr}$, the use of $\mathrm{E}_{2} \mathrm{O}_{3}(\mathrm{E}=\mathrm{As}, \mathrm{Sb})$ and $\left[\mathrm{Cr}(\mathrm{CO})_{6}\right]$ in concentrated $\mathrm{KOH} / \mathrm{MeOH}$ led to complexes of the type $\left[\mathrm{HE}\left\{\mathrm{Cr}(\mathrm{CO})_{5}\right\}_{3}\right]^{2-[4]}$ but unfortunately not for their congener Bi.

Whereas $\mathrm{Bi}-\mathrm{Fe}-\mathrm{CO}$ and $\mathrm{Bi}-\mathrm{Co}-\mathrm{CO}$ complexes are wellknown, ${ }^{[5,6]}$ previously reported $\mathrm{Bi}-\mathrm{Cr}$ - $\mathrm{CO}$ complexes are more rare: $\left[\mathrm{Cr}(\mathrm{CO})_{5} \mathrm{BiR}_{3}\right](\mathrm{R}=\mathrm{Me}, \mathrm{Et}$, cyclohexyl, $\mathrm{Ph}, t \mathrm{Bu}){ }^{[7]}$ $\left[\mathrm{Bi}\left\{\mathrm{Cr}(\mathrm{CO})_{3} \mathrm{Cp}\right\}_{3}\right],{ }^{[8]}$ and $\left[\mathrm{Ph}_{2} \mathrm{Bi}\left\{\mathrm{Cr}(\mathrm{CO})_{5}\right\}_{2}\right]^{-} .{ }^{[5 \mathrm{~g}]}$ Very recently, a closo- $\left[\left(\mu_{3}-\mathrm{Bi}\right)_{3} \mathrm{Cr}_{2}(\mathrm{CO})_{6}\right]^{2-}$ cluster anion has been discussed. ${ }^{[9]}$ Herein we report a route to a series of novel carbonylchromium complexes of bismuth: $\left[\mathrm{Et}_{4} \mathrm{~N}\right]_{3}[\mathrm{Bi}\{\mathrm{Cr}-$ $\left.\left.(\mathrm{CO})_{5}\right\}_{4}\right]\left(\left[\mathrm{Et}_{4} \mathrm{~N}\right]_{3}-\mathbf{1}\right),\left[\mathrm{Et}_{4} \mathrm{~N}\right]_{2}\left[\mathrm{MeBi}\left\{\mathrm{Cr}(\mathrm{CO})_{5}\right\}_{3}\right]\left(\left[\mathrm{Et}_{4} \mathrm{~N}\right]_{2}-\mathbf{2}\right)$,

[a] Prof. Dr. M. Shieh, J.-J. Cherng, Y.-W. Lai, Prof. Dr. C.-H. Ueng Department of Chemistry

National Taiwan Normal University

Taipei, Taiwan, 116 (Republic of China)

Fax: $(+886) 2-2932-4249$

E-mail:mshieh@scc.ntnu.edu.tw

[b] Prof. Dr. S.-M. Peng, Y.-H. Liu

Department of Chemistry

National Taiwan University

Taipei, Taiwan, 117 (Republic of China)
$\left[\mathrm{Et}_{4} \mathrm{~N}\right]_{2}\left[\mathrm{ClBi}\left\{\mathrm{Cr}(\mathrm{CO})_{5}\right\}_{3}\right] \quad\left(\left[\mathrm{Et}_{4} \mathrm{~N}\right]_{2}-\mathbf{3}\right)$, and $\left[\mathrm{Et}_{4} \mathrm{~N}\right]_{2}[\mathrm{BrBi}\{\mathrm{Cr}-$ $\left.\left.(\mathrm{CO})_{5}\right\}_{3}\right]\left(\left[\mathrm{Et}_{4} \mathrm{~N}\right]_{2}-4\right)$ and the relevance to the $\mathrm{C}-\mathrm{O}$ activation of $\mathrm{MeOH}$.

\section{Results and Discussion}

Syntheses of $\left[\mathrm{Et}_{4} \mathbf{N}\right]_{3}\left[\mathrm{Bi}\left\{\mathrm{Cr}(\mathrm{CO})_{5}\right\}_{4}\right] \quad\left[\mathrm{Et}_{4} \mathbf{N}\right]_{2}[\mathrm{MeBi}\{\mathrm{Cr}$ CO) $\left.)_{5}\right\}_{3}$ ]: By varying the sources of bismuth oxides and bases and the concentration of the bases applied, we have successfully discovered a facile route to the rare class of bismuthchromium carbonyl complexes $\left[\mathrm{Et}_{4} \mathrm{~N}\right]_{3}\left[\mathrm{Bi}\left\{\mathrm{Cr}(\mathrm{CO})_{5}\right\}_{4}\right]\left(\left[\mathrm{Et}_{4} \mathrm{~N}\right]_{3^{-}}\right.$ 1]) and $\left[\mathrm{Et}_{4} \mathrm{~N}\right]_{2}\left[\mathrm{MeBi}\left\{\mathrm{Cr}(\mathrm{CO})_{5}\right\}_{3}\right]\left(\left[\mathrm{Et}_{4} \mathrm{~N}\right]_{2}-2\right)$ from the reaction of $\mathrm{NaBiO}_{3}$ and $\left[\mathrm{Cr}(\mathrm{CO})_{6}\right]$ in a highly concentrated $\mathrm{KOH}$ methanolic solution under the different reaction conditions (Scheme 1).

$\left[\mathrm{Et}_{4} \mathrm{~N}\right]_{3}-\mathbf{1}$ was afforded in high yield from the reaction solution at ambient temperature followed by metathesis with $\left[\mathrm{Et}_{4} \mathrm{~N}\right] \mathrm{Br}$. Complex $\mathbf{1}$ is extremely reactive and its formulation as $\left[\mathrm{Bi}\left\{\mathrm{Cr}(\mathrm{CO})_{5}\right\}_{4}\right]^{3-}$ is well supported by spectroscopic characterization and elemental analyses. After numerous attempts at crystallization, the structure of $\mathbf{1}$ was finally confirmed by single-crystal $\mathrm{X}$-ray analysis (see Figure 1) to possess a tetrahedral $\mu_{4}-\mathrm{BiCr}_{4}$ core geometry in which each $\mathrm{Cr}$ atom is further coordinated with five terminal carbonyl ligands. Complex $\mathbf{1}$ can be viewed as a central $\mathrm{Bi}^{\mathrm{V}}$ ion tetrahedrally coordinated to four $\left[\mathrm{Cr}(\mathrm{CO})_{5}\right]^{2-}$ groups or alternatively be described as a complex consisting of a $\mathrm{Bi}^{3-}$ ligand coordinated through a lone pair of electrons to the $16 \mathrm{e}^{-}\left[\mathrm{Cr}(\mathrm{CO})_{5}\right]$ 


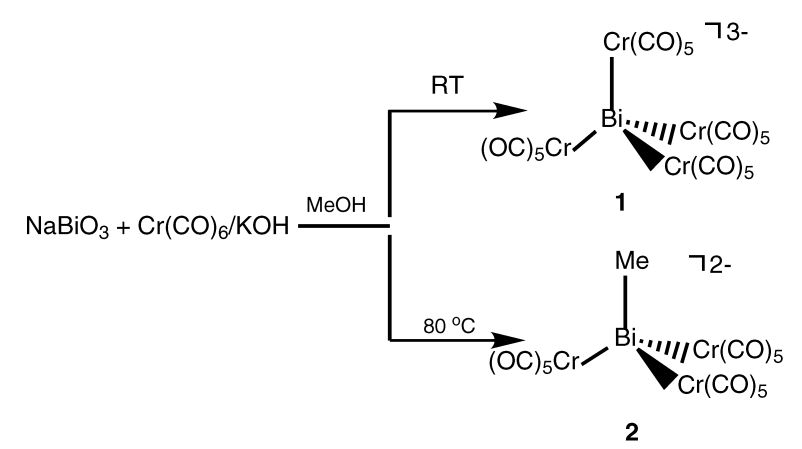

Scheme 1. Synthesis of $\mathbf{1}$ and $\mathbf{2}$ from $\mathrm{NaBiO}_{3}$ and $\left[\mathrm{Cr}(\mathrm{CO})_{6}\right] / \mathrm{KOH}$.

moieties. The assignment of the oxidation state of $\mathrm{Bi}$ is not unambiguous because of the small difference in the electronegativities of $\mathrm{Bi}$ and $\mathrm{Cr}$.

By refluxing the reaction solution at $80^{\circ} \mathrm{C}$, surprisingly, the methyl-substituted bismuth complex $\left[\mathrm{MeBi}\left\{\mathrm{Cr}(\mathrm{CO})_{5}\right\}_{3}\right]^{2-}$ (2) was obtained. The X-ray analysis of $\left[\mathrm{Et}_{4} \mathrm{~N}\right]_{2}-\mathbf{2}$, which was carried out at $150 \mathrm{~K}$ (see Figure 2), shows that the central bismuth atom is tetrahedrally coordinated to three $\left[\mathrm{Cr}(\mathrm{CO})_{5}\right]$ moieties and one Me group. The ${ }^{1} \mathrm{H}$ and ${ }^{13} \mathrm{C}$ NMR spectra of 2 display signals at $\delta=2.15$ and $-30.40 \mathrm{ppm}$, respectively, for the methyl group attached to the central bismuth atom.

The formation of $\mathbf{2}$ is believed to result from the $\mathrm{C}-\mathrm{O}$ bond cleavage of $\mathrm{MeOH}$, which is rare in the literature. Related examples were observed in the hydrothermal syntheses of telluride complexes $\left[\mathrm{M}_{4}\left(\mathrm{Te}_{2}\right)_{2}(\mathrm{Te})_{2}(\mathrm{TeMe})_{2}(\mathrm{CO})_{8}\right]^{2-}(\mathrm{M}=\mathrm{Fe}$, $\mathrm{Ru})^{[10]}$ and $\left[\mathrm{Fe}_{3} \mathrm{~W}_{2} \mathrm{Te}_{8}(\mathrm{TeMe})(\mathrm{CO})_{12}\right]^{3-[11]}$ by the employment of superheated $\mathrm{MeOH}$ solution in sealed tubes. Note that the activation of $\mathrm{C}-\mathrm{O}$ in this study is achieved under milder conditions. The cleavage of the $\mathrm{C}-\mathrm{O}$ bond of alcohol is further confirmed by the fact that the corresponding Et-substituted bismuth complex $\left[\mathrm{EtBi}\left\{\mathrm{Cr}(\mathrm{CO})_{5}\right\}_{3}\right]^{2-}$ is obtained under similar conditions in EtOH solution. The ${ }^{1} \mathrm{H}$ NMR spectrum of $\left[\mathrm{Et}_{4} \mathrm{~N}\right]_{2}\left[\mathrm{EtBi}\left\{\mathrm{Cr}(\mathrm{CO})_{5}\right\}_{3}\right]$ gives a triplet signal at $\delta=1.680 \mathrm{ppm}$ and a quartet resonance signal at $\delta=1.681 \mathrm{ppm}$, and the ${ }^{13} \mathrm{C}$ NMR spectrum displays resonances at $\delta=-30.27$ and $\delta=$ 17.92 for the ethyl group attached to the bismuth center.

Abstract in Chinese:

我們利用 $\mathrm{NaBiO}_{3}$ 與 $\mathrm{Cr}(\mathrm{CO})_{6}$ 在踰性的甲醇溶液反應下, 成功地合成一系列新顂的

含铋之铬羰基化合物。當反應控制在室溫下進行時, 可以獲得高電子價数的化 合物 $\left[\mathrm{Bi}\left\{\mathrm{Cr}(\mathrm{CO})_{5}\right\}_{4}\right]^{3-}(\mathbf{1})$, 並且經由X-光單晶绕射分析, 可知其結構是一以铋原

子為中心链結四個络羰基片断的四面船。若將反應的温度提高到 $80^{\circ} \mathrm{C}$, 則産生

了甲基取代的化合物 $\left[\mathrm{MeBi}\left\{\mathrm{Cr}(\mathrm{CO})_{5}\right\}_{3}\right]^{2-}$ (2), 推測其形成係由活化甲醇的碳一氧

链而産生。之後, 我們更進一步的研究利用 $\mathrm{CH}_{2} \mathrm{Cl}_{2}$ 或 $\mathrm{CH} \equiv \mathrm{CCH}_{2} \mathrm{Br}$ 與化合物 1 反

應, 分別得到囷基取代的化合物 $\left[\mathrm{XBi}\left\{\mathrm{Cr}(\mathrm{CO})_{5}\right\}_{3}\right]^{2-}(\mathrm{X}=\mathrm{Cl}, 3 ; \mathrm{Br}, 4)$ 。另一方面,

利用 $\mathrm{RI}(\mathrm{R}=\mathrm{Me}, \mathrm{Et})$ 與化合物 1 反應, 則可得到烷基取代的化合物

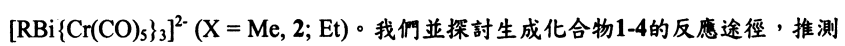

化合物 1-4的形成是經由反應中間體 $\left[\mathrm{Bi}\left\{\mathrm{Cr}(\mathrm{CO})_{5}\right\}_{3}\right]^{-}$或 $\left[\mathrm{Bi}\left\{\mathrm{Cr}(\mathrm{CO})_{5}\right\}_{3}\right]^{3-}$ 。
Reactivity of 1 : Upon stirring in $\mathrm{CH}_{2} \mathrm{Cl}_{2},\left[\mathrm{Et}_{4} \mathrm{~N}\right]_{3}-\mathbf{1}$ converts to the chloro-substituted compound $\left[\mathrm{Et}_{4} \mathrm{~N}\right]_{2}\left[\mathrm{ClBi}\left\{\mathrm{Cr}(\mathrm{CO})_{5}\right\}_{3}\right]$ $\left(\left[\mathrm{Et}_{4} \mathrm{~N}\right]_{2}-\mathbf{3}\right.$; Scheme 2), which has also been structurally

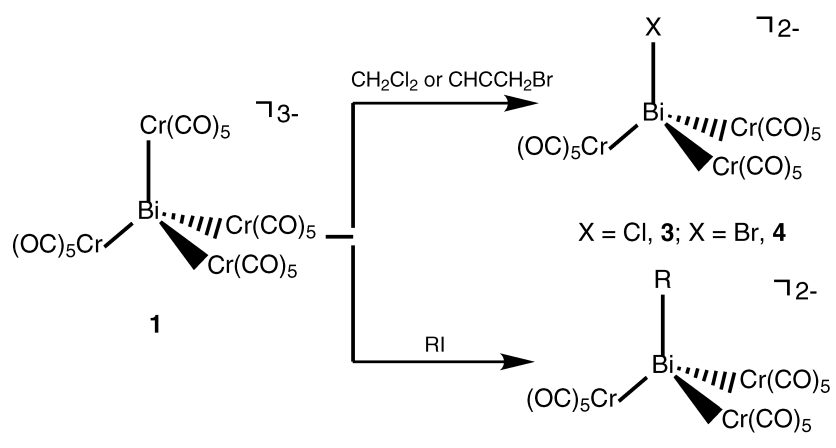

$\mathrm{R}=\mathrm{Me}, \mathbf{2} ; \mathrm{R}=\mathrm{Et}$

Scheme 2. Reactions of $\mathbf{1}$ with organic halides.

characterized by $\mathrm{X}$-ray analysis (see Figure 3). $\left[\mathrm{Et}_{4} \mathrm{~N}\right]_{3}-\mathbf{1}$ also reacts with $\mathrm{CH} \equiv \mathrm{CCH}_{2} \mathrm{Br}$ to give the bromo-substituted compound $\left[\mathrm{Et}_{4} \mathrm{~N}\right]_{2}\left[\mathrm{BrBi}\left\{\mathrm{Cr}(\mathrm{CO})_{5}\right\}_{3}\right]\left(\left[\mathrm{Et}_{4} \mathrm{~N}\right]_{2}-4\right)$. Moreover, $\left[\mathrm{Et}_{4} \mathrm{~N}\right]_{3}-\mathbf{1}$ can react with alkyl halides $\mathrm{RI}(\mathrm{R}=\mathrm{Me}, \mathrm{Et})$ to form the alkyl-substituted bismuth complexes $\left[\mathrm{Et}_{4} \mathrm{~N}\right]_{2}[\mathrm{RBi}\{\mathrm{Cr}-$ $\left.\left.(\mathrm{CO})_{5}\right\}_{3}\right](\mathrm{R}=\mathrm{Me}, 2 ; \mathrm{R}=\mathrm{Et})$. This reaction type is parallel to that of the tetrahedral bismuth complex $\left[\mathrm{Et}_{4} \mathrm{~N}\right]_{3}[\mathrm{Bi}\{\mathrm{Fe}-$ $\left.\left.(\mathrm{CO})_{4}\right\}_{4}\right]$ with alkyl halides. ${ }^{[5 \mathrm{~d}, \mathrm{e}]}$ However, the reaction of $\mathbf{1}$ toward organic halides is very sensitive to organic reagents with $\mathrm{Cl}$ or $\mathrm{Br}$ functionality due to the ease of formation of the halo-substituted bismuth complexes.

Structures of $\left[\mathrm{Me}_{4} \mathrm{~N}\right]_{3}-\mathbf{1} \cdot \mathrm{CH}_{3} \mathrm{CN}, \quad\left[\mathrm{Et}_{4} \mathrm{~N}\right]_{2}-2,\left[\mathrm{Et}_{4} \mathrm{~N}\right]_{2}-3 \cdot$ $\mathbf{C H}_{2} \mathbf{C l}_{2}$, and $\left[\mathbf{E t}_{\mathbf{4}} \mathbf{N}\right]_{2}-\mathbf{4}$ : The structures of $\mathbf{1 - 4}$ are depicted in Figure 1-4; selected bond lengths and angles are listed in Table 1 . As shown, the structures of $\mathbf{1}-\mathbf{4}$ can basically each be considered as a central bismuth atom tetrahedrally bonded to four $\left[\mathrm{Cr}(\mathrm{CO})_{5}\right]$ groups $(\mathbf{1})$ or three $\left[\mathrm{Cr}(\mathrm{CO})_{5}\right]$ groups and one other substituent, namely $\mathrm{Me}(\mathbf{2}), \mathrm{Cl}(\mathbf{3})$, or $\mathrm{Br}(\mathbf{4})$.

Very few three-coordinate bismuth complexes are known in which the lone pair on the naked bismuth center remains unavailable for further coordination..$^{[2,5]}$ Only in a few cases is the naked bismuth center four-coordinate to transition metal carbonyl fragments ${ }^{[2,5]}$ examples of the type $\mu_{4}$ - $\mathrm{BiM}_{4}$ with no $\mathrm{M}-\mathrm{M}$ bonds are limited to $\left[\mathrm{Bi}\left\{\mathrm{Fe}(\mathrm{CO})_{4}\right\}_{4}\right]^{3-}$ and $\left[\mathrm{Bi}\left\{\mathrm{Co}(\mathrm{CO})_{4}\right\}_{4}\right]^{-}{ }^{.66}$ Complexes $\mathbf{1}-\mathbf{4}$ provide a novel class of four-coordinate bismuth compounds, and more importantly, complex 1 represents the first $\mathrm{Bi}-\mathrm{Cr}$-CO tetrahedral complex with the rare $\mu_{4}-\mathrm{BiM}_{4}$ bonding mode.

For comparison, the average $\mathrm{Bi}-\mathrm{Cr}$ distances and the average $\mathrm{Cr}-\mathrm{Bi}-\mathrm{Cr}$ bond angles of complexes $\mathbf{1 - 4}$ and related compounds are listed in Table 2. Note that the average $\mathrm{Bi}-\mathrm{Cr}$ distances in $\mathbf{1}$ and $\mathbf{2}$ are 2.925 and $2.816 \AA$, respectively, which are significantly larger than the only other $\mathrm{Bi}-\mathrm{Cr}$ distances reported previously in $\left[\mathrm{Ph}_{2} \mathrm{Bi}\left\{\mathrm{Cr}(\mathrm{CO})_{5}\right\}_{2}\right]^{-}(2.750(2) \AA),{ }^{[5 \mathrm{~g}]}$ $\left[\mathrm{Ph}_{3} \mathrm{BiCr}(\mathrm{CO})_{5}\right](2.705(1) \AA),{ }^{[7 \mathrm{cc}]}\left[\mathrm{Ph}_{2} \mathrm{Bi}\left\{\mathrm{Cr}(\mathrm{CO})_{5}\right\}\left\{\mathrm{Fe}(\mathrm{CO})_{4}\right\}\right]^{-}$ $(2.722(2) \AA),{ }^{[5 \mathrm{~g}]}$ and $\left[\mathrm{Bi}\left\{\mathrm{Fe}_{2}(\mathrm{CO})_{8}\right\}\left\{\mathrm{Fe}(\mathrm{CO})_{4}\right\}\left\{\mathrm{Cr}(\mathrm{CO})_{5}\right\}\right]^{-}$ $(2.718(2) \AA) .{ }^{[j]}$ This is indicative of the weaker $\mathrm{Bi}-\mathrm{Cr}$ bonds due to steric hindrance of $\left[\mathrm{Cr}(\mathrm{CO})_{5}\right]$ groups. The $\mathrm{Bi}-\mathrm{Cr}$ distances decrease as the number of $\left[\mathrm{Cr}(\mathrm{CO})_{5}\right]$ groups and as the size of substituent ligands become smaller. Additionally, 
Table 1. Selected bond lengths $[\AA]$ and angles $\left[{ }^{\circ}\right]$ for $\left[\mathrm{Me}_{4} \mathrm{~N}\right]_{3}-\mathbf{1} \cdot \mathrm{CH}_{3} \mathrm{CN}$, $\left[\mathrm{Et}_{4} \mathrm{~N}\right]_{2}-\mathbf{2},\left[\mathrm{Et}_{4} \mathrm{~N}\right]_{2}-\mathbf{3} \cdot \mathrm{CH}_{2} \mathrm{Cl}_{2}$, and $\left[\mathrm{Et}_{4} \mathrm{~N}\right]_{2}-\mathbf{4}$.

\begin{tabular}{|c|c|c|c|}
\hline \multicolumn{4}{|c|}{$\left[\mathrm{Me}_{4} \mathrm{~N}\right]_{3}\left[\mathrm{Bi}\left\{\mathrm{Cr}(\mathrm{CO})_{5}\right\}_{4}\right] \cdot \mathrm{CH}_{3} \mathrm{CN}\left(\left[\mathrm{Me}_{4} \mathrm{~N}\right]_{3}-\mathbf{1} \cdot \mathrm{CH}_{3} \mathrm{CN}\right)$} \\
\hline $\mathrm{Bi}-\mathrm{Cr} 1$ & $2.935(1)$ & $\mathrm{Bi}-\mathrm{Cr} 2$ & $2.932(2)$ \\
\hline $\mathrm{Bi}-\mathrm{Cr} 3$ & $2.905(1)$ & $\mathrm{Bi}-\mathrm{Cr} 4$ & $2.929(2)$ \\
\hline Cr1-Bi-Cr2 & $109.70(4)$ & Cr1-Bi-Cr3 & $113.03(4)$ \\
\hline Cr1-Bi-Cr4 & $105.95(4)$ & $\mathrm{Cr} 2-\mathrm{Bi}-\mathrm{Cr} 3$ & $108.76(5)$ \\
\hline $\mathrm{Cr} 2-\mathrm{Bi}-\mathrm{Cr} 4$ & $112.19(5)$ & Cr3-Bi-Cr4 & $107.23(4)$ \\
\hline \multicolumn{4}{|c|}{$\left[\mathrm{Et}_{4} \mathrm{~N}\right]_{2}\left[\mathrm{MeBi}\left\{\mathrm{Cr}(\mathrm{CO})_{5}\right\}_{3}\right]\left(\left[\mathrm{Et}_{4} \mathrm{~N}\right]_{2}-\mathbf{2}\right)$} \\
\hline Bi1-C16 & $2.289(3)$ & Bi1-Cr1 & $2.8123(5)$ \\
\hline Bi1-Cr2 & 2.8170 & Bi1-Cr3 & $2.8195(5)$ \\
\hline C16-Bi1-Cr1 & $101.59(8)$ & $\mathrm{C} 16-\mathrm{Bi} 1-\mathrm{Cr} 2$ & $99.61(9)$ \\
\hline Cr1-Bi1-Cr2 & $115.54(2)$ & C16-Bi1-Cr3 & $101.45(9)$ \\
\hline Cr1-Bi1-Cr3 & $114.29(2)$ & $\mathrm{Cr} 2-\mathrm{Bi} 1-\mathrm{Cr} 3$ & $119.74(2)$ \\
\hline \multicolumn{4}{|c|}{$\left[\mathrm{Et}_{4} \mathrm{~N}\right]_{2}\left[\mathrm{ClBi}\left\{\mathrm{Cr}(\mathrm{CO})_{5}\right\}_{3}\right] \cdot \mathrm{CH}_{2} \mathrm{Cl}_{2}\left(\left[\mathrm{Et}_{4} \mathrm{~N}\right]_{2}-\mathbf{3} \cdot \mathrm{CH}_{2} \mathrm{Cl}_{2}\right)$} \\
\hline $\mathrm{Bi}-\mathrm{Cr} 1$ & $2.740(2)$ & $\mathrm{Bi}-\mathrm{Cr} 2$ & $2.804(2)$ \\
\hline $\mathrm{Bi}-\mathrm{Cr} 3$ & $2.763(2)$ & $\mathrm{Bi}-\mathrm{Cl} 1$ & $2.678(3)$ \\
\hline $\mathrm{Cr} 1-\mathrm{Bi}-\mathrm{Cr} 2$ & $118.32(5)$ & Cr1-Bi-Cr3 & $119.61(5)$ \\
\hline Cr1-Bi-Cl1 & $98.82(7)$ & Cr2-Bi-Cr3 & $115.69(6)$ \\
\hline Cr2-Bi-Cl1 & 98.34(8) & Cr3-Bi-Cl1 & 98.34(8) \\
\hline \multicolumn{4}{|c|}{$\left[\mathrm{Et}_{4} \mathrm{~N}\right]_{2}\left[\mathrm{BrBi}\left\{\mathrm{Cr}(\mathrm{CO})_{5}\right\}_{3}\right]\left(\left[\mathrm{Et}_{4} \mathrm{~N}\right]_{2}-\mathbf{4}\right)$} \\
\hline $\mathrm{Bi}-\mathrm{Br}$ & $2.798(1)$ & $\mathrm{Bi}-\mathrm{Cr} 1$ & $2.792(2)$ \\
\hline $\mathrm{Bi}-\mathrm{Cr} 2$ & $2.761(2)$ & $\mathrm{Bi}-\mathrm{Cr} 3$ & $2.777(2)$ \\
\hline Br-Bi-Cr1 & $99.90(5)$ & $\mathrm{Br}-\mathrm{Bi}-\mathrm{Cr} 2$ & $99.76(5)$ \\
\hline $\mathrm{Br}-\mathrm{Bi}-\mathrm{Cr} 3$ & 99.14(5) & Cr1-Bi-Cr2 & $117.49(5)$ \\
\hline Cr1-Bi-Cr3 & $116.99(5)$ & $\mathrm{Cr} 2-\mathrm{Bi}-\mathrm{Cr} 3$ & $116.99(5)$ \\
\hline
\end{tabular}

the $\mathrm{Cr}-\mathrm{Bi}-\mathrm{Cr}$ angle of $\mathbf{1}$ is smallest among $\mathbf{1}-\mathbf{4}$ due to the steric effect of the other three $\left[\mathrm{Cr}(\mathrm{CO})_{5}\right]$ groups. The $\mathrm{Cr}$ - $\mathrm{Bi}-\mathrm{Cr}$ angle of $\mathbf{3}$ is slightly larger than that of $\mathbf{4}$ owing to the smaller size of $\mathrm{Cl}$ versus $\mathrm{Br}$. The $\mathrm{Bi}-\mathrm{C}$ bond in 2 is 2.289(3) $\AA$, which is comparable to that $(2.339(1) \AA)$ in $\left[\mathrm{Bi}_{2} \mathrm{~W}_{2}(\mathrm{CO})_{8}(\mu\right.$-BiMe $\{\mathrm{W}$ $\left.\left.\left.(\mathrm{CO})_{5}\right\}\right)\right]^{[12]}$ and that $(2.32(9) \AA)$ in $\left[i \operatorname{BuBi}\left\{\mathrm{Fe}(\mathrm{CO})_{4}\right\}_{3}\right]^{2-} .{ }^{[5 \mathrm{~d}]}$

Formation of the $\mathbf{B i}-\mathbf{C r}$ complexes: The halogenation of $\mathbf{1}$ may be proposed to occur via the intermediate bismuthinidene $\left[\mathrm{Bi}\left\{\mathrm{Cr}(\mathrm{CO})_{5}\right\}_{3}\right]^{-}$, which is derived from the loss of a

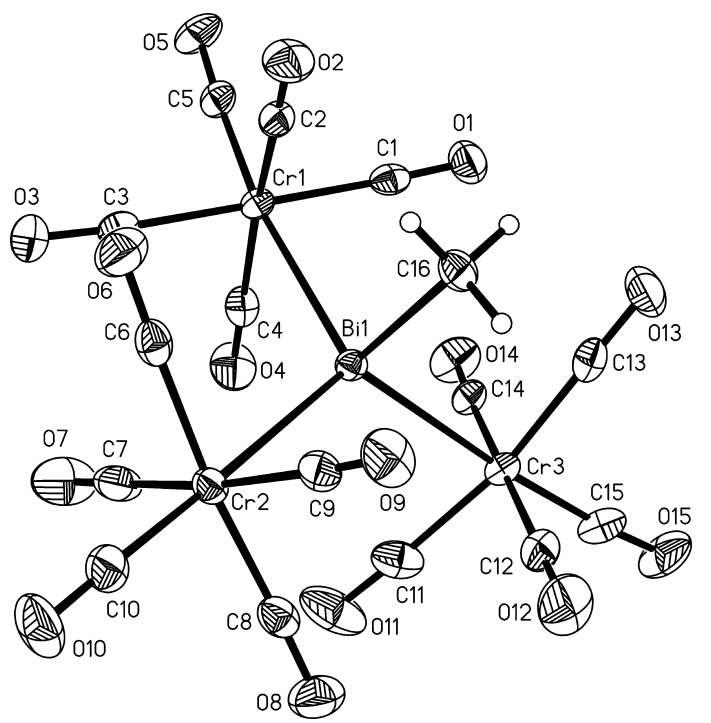

Figure 2. Structure of the dianion 2 (ORTEP diagram; $30 \%$ thermal ellipsoids).

$\left[\mathrm{Cr}(\mathrm{CO})_{5}\right]^{2-}$ fragment of $\mathbf{1}$, followed by the attack of the incoming chloride or bromide group. This assumption is based on the fact that the chloroarsinidene complex [ClAs $\{\mathrm{Cr}(-$ $\left.\mathrm{CO})_{5}\right\}_{2}$ ] can be attacked by Lewis bases to form adducts. ${ }^{[13]}$ The bismuthinidene $\left[\mathrm{Bi}\left\{\mathrm{Cr}(\mathrm{CO})_{5}\right\}_{3}\right]^{-}$is reminiscent of the extremely air-sensitive stibinidene, ${ }^{[14]}\left[\mathrm{Sb}\left\{\mathrm{Cr}(\mathrm{CO})_{5}\right\}_{3}\right]^{-}$. An alternative mechanism might involve the loss of the neutral $\left[\mathrm{Cr}(\mathrm{CO})_{5}\right]$ group from 1, leading to the formation of the intermediate anion $\left[\mathrm{Bi}\left\{\mathrm{Cr}(\mathrm{CO})_{5}\right\}\right]^{3-}$ followed by the redox processes and the attack of halides. The formation of $\left[\mathrm{Bi}\left\{\mathrm{Cr}(\mathrm{CO})_{5}\right\}\right]^{3-}$ is also conceivable in the alkylation of $\mathbf{1}$.

$\left[\mathrm{Bi}\left\{\mathrm{Cr}(\mathrm{CO})_{5}\right\}_{3}\right]^{-}$may also presumably represent an intermediate in the formation of $\mathbf{1}$ and $\mathbf{2}$ in the reaction of $\mathrm{NaBiO}_{3}$ with $\mathrm{Cr}(\mathrm{CO})_{6} / \mathrm{KOH} / \mathrm{MeOH}$. Complex 1 may result from the attack of $\left[\mathrm{Cr}(\mathrm{CO})_{5}\right]^{2-}$ on the bismuth atom of $[\mathrm{Bi}\{\mathrm{Cr}-$ $\left.\left.(\mathrm{CO})_{5}\right\}_{3}\right]^{-}$, while complex 2 is derived from the attack of $\mathrm{OMe}^{-}$on the carbonyl carbon atom followed by elimination of $\mathrm{CO}_{2}$ and then migration of the $\mathrm{Me}^{-}$group onto the bismuth center. Alternatively, the formation of $\left[\mathrm{Bi}\left\{\mathrm{Cr}(\mathrm{CO})_{5}\right\}\right]^{3-}$ as the intermediate, accompanied by redox processes is also possible. The site of attack on the bismuth center or the carbonyl carbon atom is controlled by the softness of the nucleophiles. It was proposed that the yield of 2 would be increased if the reaction were conducted under a CO atmosphere; however, the yield of $\mathbf{2}$ did not increase significantly when we carried out the reaction under a $\mathrm{CO}$

Figure 1. Structure of the trianion 1 (ORTEP diagram; $30 \%$ thermal ellipsoids).$$
\text { out the reaction under a } \mathrm{CO}
$$ 


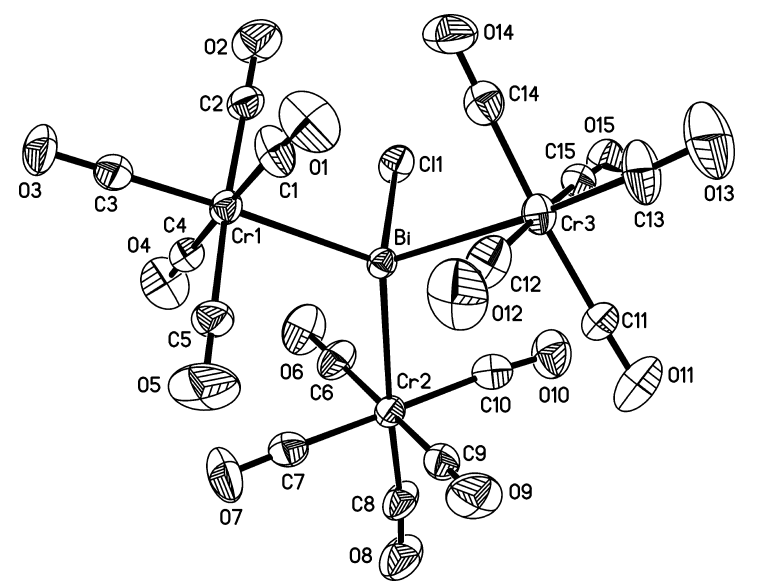

Figure 3. Structure of the dianion 3 (ORTEP diagram; $30 \%$ thermal ellipsoids).

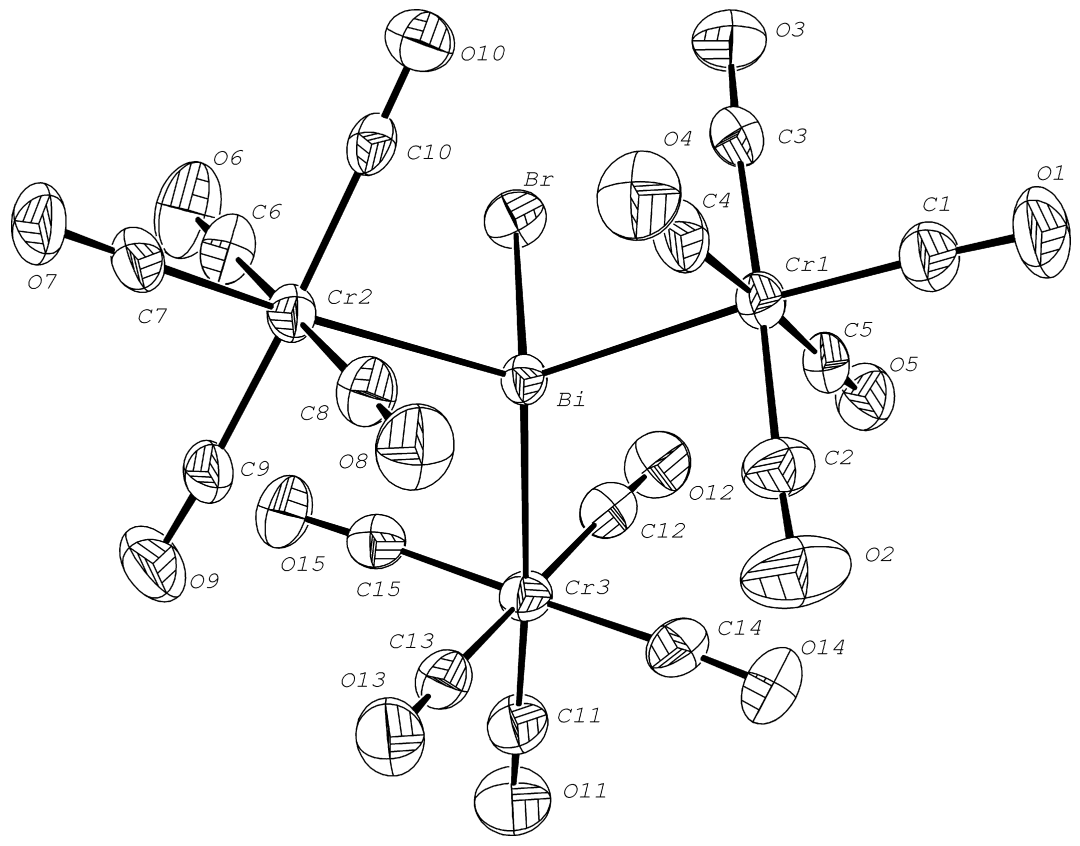

Figure 4. Structure of the dianion 4 (ORTEP diagram; $30 \%$ thermal ellipsoids).

Table 2. Average $\mathrm{Bi}-\mathrm{Cr}$ distances $[\AA]$ and $\mathrm{Cr}-\mathrm{Bi}-\mathrm{Cr}$ bond angles $\left[{ }^{\circ}\right]$ in complexes 1-4 and other related complexes.

\begin{tabular}{lll}
\hline Compounds & $\mathrm{Bi}-\mathrm{Cr}$ & Cr-Bi-Cr \\
\hline$\left[\mathrm{Me}_{4} \mathrm{~N}\right]_{3}-\mathbf{1} \cdot \mathrm{CH}_{3} \mathrm{CN}^{[a]}$ & 2.925 & 109.48 \\
{$\left[\mathrm{Et}_{4} \mathrm{~N}\right]_{2}-\mathbf{2}^{[a]}$} & 2.816 & 116.52 \\
{$\left[\mathrm{Et}_{4} \mathrm{~N}\right]_{2}-\mathbf{3} \cdot \mathrm{CH}_{2} \mathrm{Cl}_{2}^{[a]}$} & 2.769 & 117.81 \\
{$\left[\mathrm{Et}_{4} \mathrm{~N}\right]_{2}-\mathbf{4}^{[a]}$} & 2.777 & 117.28 \\
{$\left[\mathrm{Ph}_{2} \mathrm{Bi}\left\{\mathrm{Cr}(\mathrm{CO})_{5}\right\}_{2}\right]_{2}^{-[5 \mathrm{~g}]}$} & 2.750 & 125.48 \\
{$\left[\mathrm{Ph}_{3} \mathrm{BiCr}(\mathrm{CO})_{5}\right]^{[\mathrm{cc}]}$} & 2.705 & \\
\hline
\end{tabular}

[a] This work.

pressure. The decreased efficiency of $\mathrm{CO}_{2}$ elimination may be the reason for this outcome because of the external $\mathrm{CO}$ pressure applied. However, other possible mechanisms involving more complicated atom- and electron-transfer processes cannot be excluded.

\section{Conclusion}

This work describes the discovery of a new series of carbonylchromium derivatives of bismuth and the rare example of the highly charged complex $\left[\mathrm{Bi}\left\{\mathrm{Cr}(\mathrm{CO})_{5}\right\}_{4}\right]^{3-}$ with the $\mu_{4}$ - $\mathrm{Bi}$ bonding mode. Furthermore, the reactivity of $\left[\mathrm{Bi}\left\{\mathrm{Cr}(\mathrm{CO})_{5}\right\}_{4}\right]^{3-}$ with organic halides is investigated and the possible routes to the formation of $\mathbf{1 - 4}$ are discussed. This study demonstrates that the novel $\mathrm{C}-\mathrm{O}$ bond activation of alcohol can be promoted by the simple system of $\mathrm{NaBiO}_{3}$ and $\mathrm{Cr}(\mathrm{CO})_{6} / \mathrm{KOH}$, presumably via the intermediate bismuthinidene $\left[\mathrm{Bi}\left\{\mathrm{Cr}(\mathrm{CO})_{5}\right\}_{3}\right]^{-}$or the trianion $\left[\mathrm{Bi}\left\{\mathrm{Cr}(\mathrm{CO})_{5}\right\}_{3}\right]^{3-}$. Further work on useful applications of this system is in progress.

\section{Experimental Section}

All reactions were performed under an atmosphere of pure nitrogen using standard Schlenk techniques. ${ }^{[15]}$ Solvents were purified, dried, and distilled under nitrogen prior to use. Na$\mathrm{BiO}_{3}$ (ACROS), [Cr(CO) 6 (Strem), $\mathrm{Et}_{4} \mathrm{NBr}$ (Lancaster), $\mathrm{CH} \equiv \mathrm{CCH}_{2} \mathrm{Br}$ (Lancaster), were used as received. IR spectra were recorded on a PerkinElmer Paragon 500 IR spectrometer as solutions in $\mathrm{CaF}_{2}$ cells. The ${ }^{1} \mathrm{H}$ and ${ }^{13} \mathrm{C}$ NMR spectra were taken on a JEOL 400 instrument at 399.78 and $100.53 \mathrm{MHz}$, respectively. Elemental analyses of $\mathrm{C}, \mathrm{H}$, and $\mathrm{N}$ were performed on a Perkin-Elmer 2400 analyzer at the NSC Regional Instrumental Center at National Taiwan University, Taipei (Taiwan).

Synthesis of $\left[\mathrm{Et}_{4} \mathrm{~N}\right]_{3}\left[\mathrm{Bi}\left\{\mathrm{Cr}(\mathrm{CO})_{5}\right\}_{4}\right]$ $\left(\left[\mathbf{E t}_{\mathbf{4}} \mathbf{N}\right]_{\mathbf{3}} \mathbf{- 1}\right)$ : $\mathrm{MeOH}(20 \mathrm{~mL})$ was added to a mixture of $\mathrm{NaBiO}_{3}(0.217 \mathrm{~g}$, $0.78 \mathrm{mmol}), \quad \mathrm{KOH} \quad(5.589 \mathrm{~g}$, $99.6 \mathrm{mmol})$, and $\left[\mathrm{Cr}(\mathrm{CO})_{6}\right](0.685 \mathrm{~g}$, $3.11 \mathrm{mmol})$. The mixture was allowed to stir for $14 \mathrm{~h}$ at ambient temperature, and the resulting greenish-brown solution was filtered and concentrated to the appropriate volume; the product was then precipitated by addition of $\mathrm{Et}_{4} \mathrm{NBr}(0.825 \mathrm{~g}, 3.93 \mathrm{mmol})$ in aqueous solution. The precipitate was washed with deionized water and THF several times and was then extracted with $\mathrm{MeCN}$ to give the greenish-brown sample of $\left[\mathrm{Et}_{4} \mathrm{~N}\right]_{3}-\mathbf{1}$. Yield: $0.81 \mathrm{~g}, 0.59 \mathrm{mmol} ; 76 \%$ (based on $\mathrm{Bi}$ ). Crystals suitable for X-ray analysis were grown from $\mathrm{MeCN}$ by using the $\left[\mathrm{Me}_{4} \mathrm{~N}\right]^{+}$salts. IR $(\mathrm{MeCN})$ : $\tilde{v}_{\mathrm{co}}=1982$ (vs), 1930 (w), 1899 (s), 1859 (w), 1826 (s) $\mathrm{cm}^{-1}$; elemental analysis (\%) calcd for $\left[\mathrm{Me}_{4} \mathrm{~N}\right]_{3}-\mathbf{1} \cdot \mathrm{CH}_{3} \mathrm{CN}$ : C 32.92, H 3.17, N 4.52; found: C 32.78, H 3.10, N 4.33 .

Synthesis of $\left[\mathbf{E t}_{4} \mathbf{N}\right]_{2}\left[\mathrm{MeBi}\left\{\mathbf{C r}(\mathbf{C O})_{5}\right\}_{3}\right]\left(\left[\mathbf{E t}_{4} \mathbf{N}\right]_{2}-\mathbf{2}\right)$ : $\mathrm{MeOH}(20 \mathrm{~mL})$ was added to a mixture of $\mathrm{NaBiO}_{3}(0.180 \mathrm{~g}, 0.64 \mathrm{mmol}), \mathrm{KOH}(5.880 \mathrm{~g}$, $105 \mathrm{mmol})$, and $\left[\mathrm{Cr}(\mathrm{CO})_{6}\right](0.582 \mathrm{~g}, 2.58 \mathrm{mmol})$. The mixture was allowed to stir for $18 \mathrm{~h}$ at $80^{\circ} \mathrm{C}$. The solution was filtered and concentrated, and the product was then precipitated by the addition of $\mathrm{Et}_{4} \mathrm{NBr}$ in aqueous solution. The precipitate was then washed with deionized water several times and extracted with THF to give the reddish-brown sample of $\left[\mathrm{Et}_{4} \mathrm{~N}\right]_{2^{-}}$ 2. Yield: $0.42 \mathrm{~g}, 0.40 \mathrm{mmol} ; 62 \%$ (based on $\mathrm{Bi}$ ). IR (THF): $\tilde{v}_{\mathrm{CO}}=1993$ (vs), 1917 (vs), 1854 (s) cm ${ }^{-1}$; elemental analysis (\%) calcd for $\left[\mathrm{Et}_{4} \mathrm{~N}\right]_{2}-\mathbf{2}$ : C 36.24, $\mathrm{H}$ 4.09, N 2.64; found: C 35.97, H 3.76, N 2.53; ${ }^{1} \mathrm{H}$ NMR $(400 \mathrm{MHz}$, $\left.\left[\mathrm{D}_{6}\right] \mathrm{DMSO}, 298 \mathrm{~K}\right): \delta=2.15 \mathrm{ppm} \quad\left(\mathrm{s}, \mathrm{CH}_{3}\right) ;{ }^{13} \mathrm{C} \quad \mathrm{NMR} \quad(100 \mathrm{MHz}$, $\left[\mathrm{D}_{6}\right] \mathrm{DMSO}, 298 \mathrm{~K}$ ): $\delta=-30.40 \mathrm{ppm}$ (the chemical shifts for $\left[\mathrm{Et}_{4} \mathrm{~N}\right]^{+}$are not given). 
Synthesis of $\left[\mathrm{Et}_{4} \mathbf{N}\right]_{2}\left[\operatorname{EtBi}\left\{\mathrm{Cr}(\mathrm{CO})_{5}\right\}_{3}\right]$ EtOH $(20 \mathrm{~mL})$ was added to a mixture of $\mathrm{NaBiO}_{3}(0.18 \mathrm{~g}, 0.64 \mathrm{mmol}), \mathrm{KOH}$ $(5.73 \mathrm{~g}, 102 \mathrm{mmol})$, and $\left[\mathrm{Cr}(\mathrm{CO})_{6}\right]$ $(0.83 \mathrm{~g}, 3.95 \mathrm{mmol})$. The mixture was allowed to stir for $18 \mathrm{~h}$ at $80^{\circ} \mathrm{C}$. The solution was filtered and concentrated, and then the product was precipitated by the addition of $\mathrm{Et}_{4} \mathrm{NBr}$ in aqueous solution. The precipitate was then washed with deionized water several times and extracted with THF to give the reddish-brown sample of $\left[\mathrm{Et}_{4}\right.$ $\mathrm{N}]_{2}\left[\operatorname{EtBi}\left\{\mathrm{Cr}(\mathrm{CO})_{5}\right\}_{3}\right]$. Yield: $0.33 \mathrm{~g}$, $0.31 \mathrm{mmol} ; 48 \%$ (based on $\mathrm{Bi}$ ). IR (THF): $\tilde{v}_{\mathrm{CO}}=1994$ (vs), 1914 (vs), 1849 (s) $\mathrm{cm}^{-1}$; elemental analysis (\%) calcd for $\left[\mathrm{Et}_{4} \mathrm{~N}\right]_{2}\left[\mathrm{EtBi}\left\{\mathrm{Cr}(\mathrm{CO})_{5}\right\}_{3}\right]: \mathrm{C} 36.88$, H 4.22, N 2.61; found: C 36.32, H 3.91, $\mathrm{N} \quad 2.66 ;{ }^{1} \mathrm{H} \quad \mathrm{NMR} \quad(400 \mathrm{MHz}$, $\left.\left[\mathrm{D}_{6}\right] \mathrm{DMSO}, 298 \mathrm{~K}\right): \delta=1.69(\mathrm{t}, J=$ $\left.16 \mathrm{~Hz} ; \mathrm{CH}_{3}\right), 2.44 \mathrm{ppm}(\mathrm{q}, J=16 \mathrm{~Hz}$; $\left.\mathrm{CH}_{2}\right) ; \quad{ }^{13} \mathrm{C}$ NMR $\quad(100 \mathrm{MHz}$ $\left.\left[\mathrm{D}_{6}\right] \mathrm{DMSO}, 298 \mathrm{~K}\right): \delta=-30.27\left(\mathrm{CH}_{2}\right)$, $17.92 \mathrm{ppm}\left(\mathrm{CH}_{3}\right)$ (the chemical shifts for $\left[\mathrm{Et}_{4} \mathrm{~N}\right]^{+}$are not given)

Reaction of $\left[\mathrm{Et}_{4} \mathbf{N}\right]_{3}\left[\mathrm{Bi}\left\{\mathrm{Cr}(\mathrm{CO})_{5}\right\}_{4}\right]$ $\left(\left[\mathrm{Et}_{4} \mathbf{N}_{3}-\mathbf{1}\right)\right.$ with $\quad \mathbf{C H}_{2} \mathrm{Cl}_{2}: \quad \mathrm{CH}_{2} \mathrm{Cl}_{2}$ $(20 \mathrm{~mL})$ was added to a sample of $\left[\mathrm{Et}_{4} \mathrm{~N}\right]_{3}-1 \quad(0.24 \mathrm{~g}, \quad 0.18 \mathrm{mmol})$. The mixed solution was allowed to stir for $14 \mathrm{~h}$ at room temperature. The resulting greenish-brown solution was filtered and the solvent was removed under vacuum. The residue was extracted with THF and recrystallized by

$\mathrm{Et}_{2} \mathrm{O} / \mathrm{CH}_{2} \mathrm{Cl}_{2}$ to give $\left[\mathrm{Et}_{4} \mathrm{~N}\right]_{2}\left[\mathrm{ClBi}\left\{\mathrm{Cr}(\mathrm{CO})_{5}\right\}_{3}\right]\left(\left[\mathrm{Et}_{4} \mathrm{~N}\right]_{2}-3\right)$. Yield: $0.09 \mathrm{~g}$, $0.08 \mathrm{mmol} ; 44 \%$ (based on $\left[\mathrm{Et}_{4} \mathrm{~N}\right]_{3}-1$ ). IR (THF): $\tilde{v}_{\mathrm{CO}}=2009$ (vs), 1930 (vs), $1867(\mathrm{~s}) \mathrm{cm}^{-1}$; elemental analysis $(\%)$ calcd for $\left[\mathrm{Et}_{4} \mathrm{~N}\right]_{2}\left[\mathrm{ClBi}\left\{\mathrm{Cr}(\mathrm{CO})_{5}\right\}_{3}\right]: \mathrm{C}$ 34.44, H 3.73, N 2.59; found: C 33.81, H 3.82, N 2.55.

Reaction of $\left[\mathrm{Et}_{4} \mathbf{N}\right]_{3}\left[\mathrm{Bi}\left\{\mathrm{Cr}(\mathrm{CO})_{5}\right\}_{4}\right] \quad\left(\left[\mathrm{Et}_{4} \mathbf{N}\right]_{3}-1\right)$ with $\mathbf{C H} \equiv \mathrm{CCH}_{2} \mathrm{Br}$ : $\mathrm{CH} \equiv \mathrm{CCH}_{2} \mathrm{Br}(0.1 \mathrm{~mL}, 1.32 \mathrm{mmol})$ was added to a solution of $\left[\mathrm{Et}_{4} \mathrm{~N}\right]_{3}-\mathbf{1}$ $(0.33 \mathrm{~g}, 0.24 \mathrm{mmol})$ in $\mathrm{MeCN}(20 \mathrm{~mL})$ in an ice/water bath. The mixture was stirred in an ice/water bath for $2 \mathrm{~h}$. The resultant solution was filtered to collect the filtrate, and the solvent was removed under vacuum. The residue was extracted with THF, and the extract was recrystallized with $\mathrm{THF} / \mathrm{Et}_{2} \mathrm{O}$ to give $\left[\mathrm{Et}_{4} \mathrm{~N}\right]_{2}\left[\mathrm{BrBi}\left\{\mathrm{Cr}(\mathrm{CO})_{5}\right\}_{3}\right]\left(\left[\mathrm{Et}_{4} \mathrm{~N}\right]_{2}-4\right)$. Yield: $0.22 \mathrm{~g}, 0.20 \mathrm{mmol} ; 81 \%$ (based on $\left[\mathrm{Et}_{4} \mathrm{~N}\right]_{3}-\mathbf{1}$ ). IR (THF): $\tilde{v}_{\mathrm{CO}}=2007$ (vs), 1932 (vs), 1922 (vs), 1867 (s) $\mathrm{cm}^{-1}$; elemental analysis $(\%)$ calcd for $\left[\mathrm{Et}_{4} \mathrm{~N}\right]_{2}\left[\mathrm{BrBi}\left\{\mathrm{Cr}(\mathrm{CO})_{5}\right\}_{3}\right]$ : C 33.08, H 3.58, N 2.49; found: C 33.07, H 3.48, N 2.73.

Reaction of $\left[\mathbf{E t}_{4} \mathbf{N}\right]_{3}\left[\mathbf{B i}\left\{\mathbf{C r}(\mathbf{C O})_{5}\right\}_{4}\right]\left(\left[\mathbf{E t}_{4} \mathbf{N}\right]_{3}-1\right)$ with MeI: MeI $(0.04 \mathrm{~mL}$, $0.64 \mathrm{mmol})$ in $\mathrm{CH}_{3} \mathrm{CN}(20 \mathrm{~mL})$ was added to a sample of $\left[\mathrm{Et}_{4} \mathrm{~N}\right]_{3}-\mathbf{1}(0.52 \mathrm{~g}$, $0.38 \mathrm{mmol}$ ). The mixed solution was allowed to stir for $40 \mathrm{~min}$ at room temperature. The resulting purplish-red solution was filtered and the solvent was removed under vacuum. The residue was extracted with THF and recrystallized by $\mathrm{THF} / \mathrm{Et}_{2} \mathrm{O}$ to give $\left[\mathrm{Et}_{4} \mathrm{~N}\right]_{2}-2$. Yield: $0.25 \mathrm{~g}, 0.24 \mathrm{mmol}$; $63 \%$ (based on $\left[\mathrm{Et}_{4} \mathrm{~N}\right]_{3}-\mathbf{1}$ )

Reaction of $\left[\mathbf{E t}_{4} \mathbf{N}\right]_{3}\left[\mathbf{B i}\left\{\mathbf{C r}(\mathbf{C O})_{5}\right\}_{4}\right]\left(\left[\mathbf{E t}_{4} \mathbf{N}\right]_{3}-\mathbf{1}\right)$ with EtI: EtI $(0.04 \mathrm{~mL}$, $0.50 \mathrm{mmol})$ in $\mathrm{CH}_{3} \mathrm{CN}(20 \mathrm{~mL})$ was added to a sample of $\left[\mathrm{Et}_{4} \mathrm{~N}\right]_{3}-\mathbf{1}(0.41 \mathrm{~g}$, $0.30 \mathrm{mmol}$ ). The mixed solution was allowed to stir for $2.5 \mathrm{~h}$ at room temperature. The resulting purplish-red solution was filtered and the solvent was removed under vacuum. The residue was extracted with THF and recrystallized by $\mathrm{THF} / \mathrm{Et}_{2} \mathrm{O}$ to give $\left[\mathrm{Et}_{4} \mathrm{~N}\right]_{3}\left[\mathrm{EtBi}\left\{\mathrm{Cr}(\mathrm{CO})_{5}\right\}_{3}\right]$. Yield: $0.29 \mathrm{~g}, 0.27 \mathrm{mmol} ; 90 \%$ (based on $\left[\mathrm{Et}_{4} \mathrm{~N}\right]_{3}-\mathbf{1}$ ).

$\mathrm{X}$-ray structural characterization of complexes $\left[\mathrm{Me}_{4} \mathrm{~N}_{3}-1 \cdot \mathrm{CH}_{3} \mathrm{CN}\right.$, $\left[\mathrm{Et}_{4} \mathbf{N}\right]_{2}-\mathbf{2},\left[\mathrm{Et}_{4} \mathbf{N}\right]_{2}-\mathbf{3} \cdot \mathrm{CH}_{2} \mathrm{Cl}_{2}$, and $\left[\mathrm{Et}_{4} \mathbf{N}_{2}-\mathbf{4}\right.$ : A summary of selected crystallographic data for $\left[\mathrm{Me}_{4} \mathrm{~N}\right]_{3} \mathbf{- 1} \cdot \mathrm{CH}_{3} \mathrm{CN},\left[\mathrm{Et}_{4} \mathrm{~N}\right]_{2}-\mathbf{2},\left[\mathrm{Et}_{4} \mathrm{~N}\right]_{2}-\mathbf{3} \cdot \mathrm{CH}_{2} \mathrm{Cl}_{2}$, $\left[\mathrm{Et}_{4} \mathrm{~N}_{2}-\mathbf{4}\right.$ are given in Table 3. All crystals were mounted on glass fibers with Epoxy cement. Data collection of $\left[\mathrm{Me}_{4} \mathrm{~N}\right]_{3}-\mathbf{1} \cdot \mathrm{CH}_{3} \mathrm{CN}$ and $\left[\mathrm{Et}_{4} \mathrm{~N}\right]_{2}-\mathbf{4}$ was carried out on a Nonius CAD-4 diffractometer using graphite- monochromated $\mathrm{Mo}_{\mathrm{K} \alpha}$ radiation at $25^{\circ} \mathrm{C}$ employing the $\theta / 2 \theta$ scan mode Cell parameters were obtained from 25 reflections with $2 \theta$ angle in the range $18.52-24.14^{\circ}$ for $\left[\mathrm{Me}_{4} \mathrm{~N}\right]_{3}-\mathbf{1} \cdot \mathrm{CH}_{3} \mathrm{CN}, 1.00<\theta<25.00^{\circ}$ for $\left[\mathrm{Et}_{4} \mathrm{~N}\right]_{2}-\mathbf{2}$, $1.92<\theta<27.47^{\circ}$ for $\left[\mathrm{Et}_{4} \mathrm{~N}\right]_{2}-\mathbf{3} \cdot \mathrm{CH}_{2} \mathrm{Cl}_{2}, 19.04<2 \theta<25.08^{\circ}$ for $\left[\mathrm{Et}_{4} \mathrm{~N}\right]_{2}-\mathbf{4}$. A $\psi$ scan absorption correction was made. ${ }^{[16]}$ Data reduction and structural refinement were performed using the NRCC-SDP-VAX packages, ${ }^{[17]}$ and atomic scattering factors were taken from International Table for $X$-ray Crystallography. ${ }^{[18]}$ Data collection for $\left[\mathrm{Et}_{4} \mathrm{~N}\right]_{2}-\mathbf{2}$ and $\left[\mathrm{Et}_{4} \mathrm{~N}\right]_{2}-\mathbf{3} \cdot \mathrm{CH}_{2} \mathrm{Cl}_{2}$ was carried out on a SMART CCD diffractometer. A SADABS scan absorption correction was made, ${ }^{[19]}$ and all calculations were performed using SHELXTL packages. ${ }^{[2]}$ All the non-hydrogen atoms were refined with anisotropic temperature factors. CCDC-181785 $\left(\left[\mathrm{Me}_{4} \mathrm{~N}\right]_{3}[\mathbf{1}] \cdot \mathrm{CH}_{3} \mathrm{CN}\right)$, CCDC-172341 ([Et $\left.{ }_{4} \mathrm{~N}_{2}[\mathbf{2}]\right), \quad \mathrm{CCDC}-172342\left(\left[\mathrm{Et}_{4} \mathrm{~N}\right]_{2}[\mathbf{3}] \cdot \mathrm{CH}_{2} \mathrm{Cl}_{2}\right)$ and CCDC-181786 $\left(\left[\mathrm{Et}_{4} \mathrm{~N}\right]_{2}[4]\right)$ contain the supplementary crystallographic data for this paper. These data can be obtained free of charge via www.ccdc.can.ac.uk/conts/retrieving.html (or from the Cambridge Crystallographic Center, 12 Union Road, Cambridge CB21EZ, UK; Fax: (+44)1223-336033; or deposit@ccdc.cam.ac.uk).

\section{Acknowledgement}

This work was supported by the National Science Council of Republic of China (Grant No. 90-2113-M-003-018 to M. Shieh) and by National Taiwan Normal University (ORD 91-1).

[1] a) W. Hieber, J. Gruber, F. Lux, Z. Anorg. Allg. Chem. 1959, 300, 275; b) W. Hieber, W. Beck, Z. Anorg. Allg. Chem. 1960, 305, 265; c) W. Hieber, J. Gruber, Z. Anorg. Allg. Chem. 1958, 296, 91.

[2] a) W. A. Herrmann, Angew. Chem. 1986, 98, 57; Angew. Chem. Int Ed. Engl. 1986, 25, 56; b) N. A. Compton, R. J. Errington, N. C. Norman, Adv. Organomet. Chem. 1990, 31, 91; c) O. J. Scherer, Comments Inorg. Chem. 1987, 6, 1; d) O. J. Scherer, Angew. Chem. 1985, 97, 905; Angew. Chem. Int. Ed. Engl. 1985, 24, 924; e) K. H. Whitmire, J. Coord. Chem. 1988, 17, 95; f) G. Huttner, K. Evertz, Acc. 
Chem. Res. 1986, 19, 406; g) H. Vahrenkamp, Adv. Organomet. Chem. 1983, 22, 169; h) O. J. Scherer, Angew. Chem. 1990, 102, 1137; Angew. Chem. Int. Ed. Engl. 1990, 29, 1104; i) A. H. Cowley, J. Organomet. Chem. 1990, 400, 71; j) K. H. Whitmire, J. Cluster Sci. 1991, 2, 231; k) K. H. Whitmire, J. Adv. Organomet. Chem. 1997, 42, 1.

[3] a) M. Shieh, H.-S. Chen, H.-Y. Yang, C.-H. Ueng, Angew. Chem. 1999 , 111, 1339; Angew. Chem. Int. Ed. Engl. 1999, 38, 1252; b) M. Shieh, H.-S. Chen, H.-Y. Yang, S.-F. Lin, C.-H. Ueng, Chem. Eur. J. 2001, 7, 3152.

[4] a) J.-J. Cherng, G.-H. Lee, S.-M. Peng, C.-H. Ueng, M. Shieh, Organometallics 2000, 19, 213; b) J.-J. Cherng, Y.-W. Lai, Y.-H. Liu, S.-M. Peng, C.-H. Ueng, M. Shieh, Inorg. Chem. 2001, 40, 1206.

[5] a) G. Schmid, G. Etzrodt, J. Orgnomet. Chem. 1977, 137, 367; b) W. Kruppa, D. Bläser, R. Boese, G. Schmid, Z. Naturforsch. 1982, B37, 209; c) K. H. Whitmire, M. Shieh, C. B. Lagrone, B. H. Robinson, M. R. Churchill, J. C. Fettinger, R. F. See, Inorg. Chem. 1987, 26, 2798; d) M. Shieh, Y. Liou, S.-M. Peng, G.-H. Lee, Inorg. Chem. 1993, 32, 2212; e) M. Shieh, Y. Liou, B.-W. Jeng, Organometallics 1993, 12, 4926; f) J. M. Cassidy, K. H. Whitmire, Inorg. Chem. 1991, 30, 2788; g) R. E. Backman, K. H. Whitmire, Inorg. Chem. 1995, 34, 1542; h) T. Gröer, M. Scheer, Organometallics 2000, 19, 3683; i) M. Shieh, F.-D. Mia, S.-M. Peng, G.-H. Lee, Inorg. Chem. 1993, 32, 2785; j) K. H. Whitmire, M. Shieh, J. Cassidy, Inorg. Chem. 1989, 28, 3164.

[6] a) M. R. Churchill, J. C. Fettinger, K. H. Whitmire, C. B. Lagrone, J. Organomet. Chem. 1986, 303, 99; b) K. H. Whitmire, M. R. Churchill, J. C. Fettinger, J. Am. Chem. Soc. 1985, 107, 1056; c) J. S. Leigh, K. H. Whitmire, Angew. Chem. 1988, 100, 399; Angew. Chem. Int. Ed. Engl. 1988, 27, 396.

[7] a) E. O. Fischer, K. Richter, Chem. Ber. 1976, 109, 1140; b) D. Benlian, M. Bigorgne, Bull. Soc. Chim. Fr. 1963, 1583; c) A. J. Carty, N. J.
Taylor, A. W. Coleman, M. F. Lappert, J. Chem. Soc. Chem. Commun. 1979, 639; d) H. Schumann, H. J. Breunig, J. Organomet. Chem. 1975, 87,83 .

[8] W. Clegg, N. A. Compton, R. J. Errington, G. A. Fisher, N. C. Norman, T. B. Marder, J. Chem. Soc. Dalton Trans. 1991, 2887.

[9] L. Xu, A. Ugrinov, S. C. Sevov, J. Am. Chem. Soc. 2001, 123, 4091.

[10] B. K. Das, M. G. Kanatzidis, Inorg. Chem. 1995, 34, 1011.

[11] B. K. Das, M. G. Kanatzidis, Inorg. Chem. 1995, 34, 5725.

[12] a) A. M. Arif, A. H. Cowley, N. C. Norman, M. Pakulski, J. Am. Chem. Soc. 1985, 107, 1062; b) A. M. Arif, A. H. Cowley, N. C. Norman, M. Pakulski, Inorg. Chem. 1986, 25, 4836.

[13] J. von Seyerl, G. Huttner, Angew. Chem. 1979, 91, 244; Angew. Chem. Int. Ed. Engl. 1979, 18, 233.

[14] G. Huttner, U. Weber, B. Sigwarth, O. Scheidsteger, H. Lang, L. Zsolnai, J. Organomet. Chem. 1985, 282, 331.

[15] D. F. Shriver, M. A. Drezdzon, The Manupulation of Air Sensitive Compounds, Wiley, New York, 1986.

[16] A. C. T. North, D. C. Philips, F. S. Mathews, Acta Crystallogr. Sect. A 1968, 24, 351.

[17] E. J. Gabe, Y. Le Page, J. P. Charland, F. L. Lee, P. S. White, J. Appl. Crystallogr. 1989, 22, 384.

[18] International Tables for X-ray Crystallography; Vol. IV, Kynoch press, Birmingham, England, 1974.

[19] G. M. Sheldrick, SADABS, Siemens Area Detector Absorption Correction Program, University of Göttingen, Germany, 1996.

[20] G. M. Sheldrick, SHELXTL, Program for Crystal Structure Detection, Siemens Analytical X-ray Instruments Inc., Madison, WI, 1994.

Received: April 17, 2002 [F4025] 